Article

\title{
Comparing the Performance of Four Very Large Marine Protected Areas with Different Levels of Protection
}

\author{
Veronica Relano*(D), Maria Lourdes Deng Palomares (D) and Daniel Pauly (D) \\ Sea Around Us, Institute for the Oceans and Fisheries, University of British Columbia, Vancouver BC V6T \\ 1Z4, Canada; m.palomares@oceans.ubc.ca (M.L.D.P.); d.pauly@oceans.ubc.ca (D.P.) \\ * Correspondence: v.relano@oceans.ubc.ca
}

Citation: Relano, V.; Palomares, M.L.D.; Pauly, D. Comparing the Performance of Four Very Large Marine Protected Areas with Different Levels of Protection. Sustainability 2021, 13, 9572. https:// doi.org/10.3390/su13179572

Academic Editor: Iain J. Gordon

Received: 16 July 2021

Accepted: 22 August 2021

Published: 25 August 2021

Publisher's Note: MDPI stays neutral with regard to jurisdictional claims in published maps and institutional affiliations.

Copyright: (c) 2021 by the authors. Licensee MDPI, Basel, Switzerland. This article is an open access article distributed under the terms and conditions of the Creative Commons Attribution (CC BY) license (https:// creativecommons.org/licenses/by/ $4.0 /)$.
Abstract: In the last decades, several targets for marine conservation were set to counter the effects of increasing fishing pressure, e.g., protecting $10 \%$ of the sea by 2020 , and establishing large-scale marine protected areas (LSMPAs). Using the 'reconstructed' catch data for 1950 to 2018 made available by the Sea Around Us initiative, we show that the declaration of an exclusive economic zone (EEZ) in 1983 by the U.S.A. and its protection by the U.S. Coast Guard had a much bigger impact on catches around the Northwestern Hawaiian Islands than the subsequent creation of a LSMPA. This is similar to Pitcairn Islands, a UK territory. Trends differed sharply in the Galapagos and New Caledonia, where neither their EEZ declaration nor the LSMPA (by Ecuador in 1988 and by France in 2014) stopped local fisheries from continuous expansion. Our results also demonstrate that in the studied multizone LSMPAs continued local fishing induces a 'fishing down' effect wherein the mean trophic level (TL) declined, especially in the Galapagos, by 0.1 TL per decade. Stakeholders' responses to a short questionnaire and satellite imagery lent support to these results in that they documented substantial fishing operations and 'fishing the line' within and around multizone LSMPAs. In the case of EEZs around less populated or unpopulated islands, banning foreign fishing may reduce catch much more than a subsequent LSMPA declaration. This confirms that EEZs are a tool for coastal countries to protect their marine biodiversity and that allowing fishing in an MPA, while politically convenient, may result in 'paper parks' within which fishing can cause the same deleterious effects as in wholly unprotected areas.

Keywords: large scale marine protected area (LSMPA); conservation priority; biodiversity; fisheries; exclusive economic zone (EEZ); ecosystem effects of fishing

\section{Introduction}

Globally, there is an increased awareness of the multiple threats to biodiversity in general, and marine biodiversity in particular. In the Pacific, the idea of protecting certain areas is anchored in the ancient notion of sacred sites, "tapu" areas, a traditional Polynesian concept [1]. Over the last century, this idea has evolved, and it is now globally accepted and implemented under the concept of marine protected areas $[2,3]$.

Under the IUCN (International Union for Conservation of Nature) definition, the primary objective of an MPA must be to conserve nature under specific management objectives [4]. In practice, well-managed MPAs do not only conserve nature within the MPA, but also in the surroundings contributing to economic, recreational and cultural value to society providing crucial and sustainable ecosystem services, including biodiversity, food security and fish spilling out of their boundaries [5-7]. Existing MPAs vary from strict 'no-take' areas to sites where the use of natural resources is deemed compatible with conservation [8], often with boundaries that limit these activities within zones-so called 'multi-use MPAs'. On the other hand, no-take MPAs are here considered equivalent to the strict nature reserve category of the IUCN system. Under this definition, a marine reserve is an area that strictly protects its biodiversity and geological features from all human uses 
and activities, except for specific and well-regulated research and monitoring, no matter its size [9].

This study focuses on the performance in regards to the fishing pressure applied to various commercial marine species across four large scale marine protected areas (LSMPAs) in four different exclusive economic zones (EEZ) in the Pacific (Hawaii, Pitcairn, Galapagos, New Caledonia; Figure 1). While there is some controversy around the definition of LSMPAs regarding their extension and the activities allowed within them, here, LSMPAs are usually considered to refer to marine protected areas in excess of $100,000 \mathrm{~km}^{2}$, where the allowed activities identify the IUCN category that it belongs to [10-13]. The four LSMPAs of this study are characterized by different levels of protection, i.e., they are either classified as $100 \%$ no-take (in Northwestern Hawaii and Pitcairn) or divided into different zones with varying levels of protection (multi-use; New Caledonia, Galapagos). We selected these four well-documented LSMPAs in the Pacific to compare the effect of their EEZ enforcement to the declaration of no-take or multi-use MPAs (Table 1).

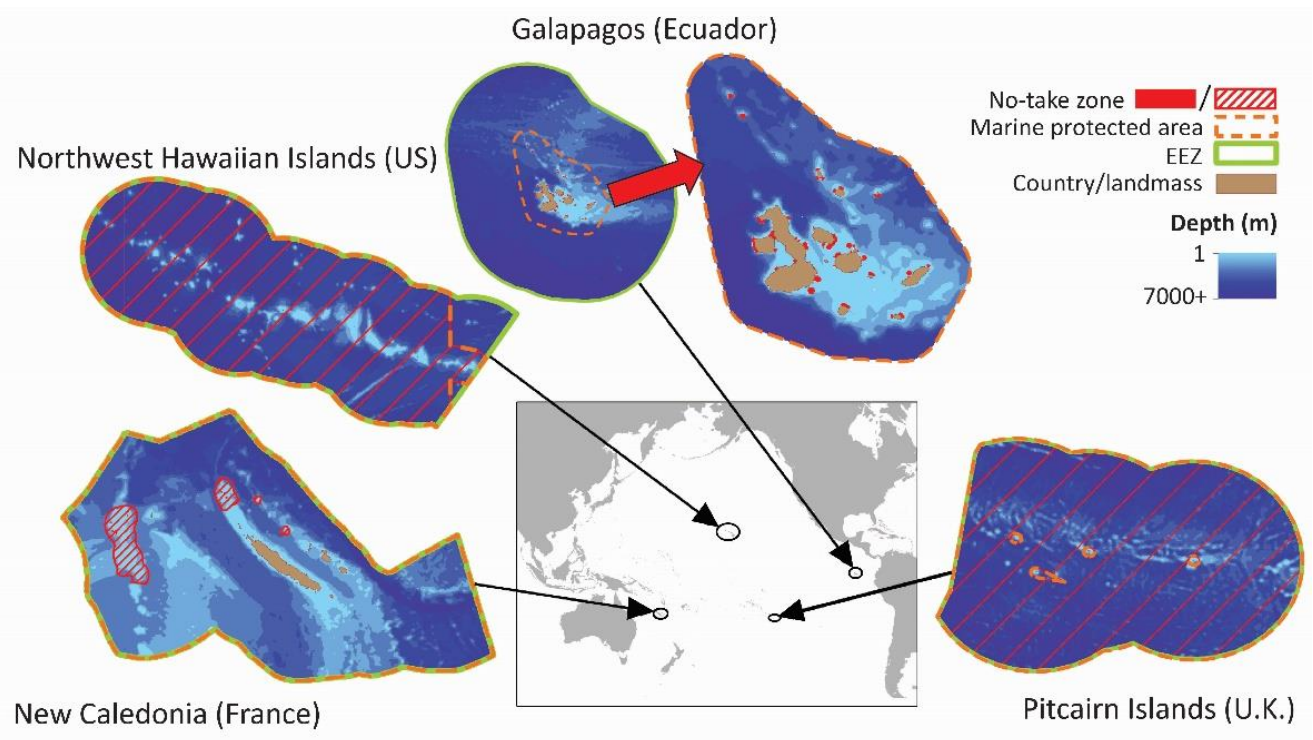

Figure 1. The EEZ of the four Pacific study sites included in this study, with information on their bathymetry, and their no-take borders (see also Table 1). The no-take LSMPAs are situated in the Northwest Hawaiian Islands $\left(25^{\circ} \mathrm{N}\right.$ and $\left.169^{\circ} \mathrm{W}\right)$ and in Pitcairn Islands $\left(25^{\circ} 04^{\prime} \mathrm{S}\right.$ and $\left.130^{\circ} 06^{\prime} \mathrm{W}\right)$. The multi-use LSMPAs are around the Galapagos $\left(0^{\circ} 30^{\prime} \mathrm{S}\right.$ and $\left.90^{\circ} 30^{\prime} \mathrm{W}\right)$ and New Caledonia $\left(22^{\circ} 16^{\prime}\right.$ $S$ and $\left.166^{\circ} 28^{\prime} \mathrm{E}\right)$.

Performance is defined as "manner or quality of functioning", and it refers here to the degree of compliance with one of the main purposes of MPAs: protecting marine ecosystems from having their biodiversity fished out of them. Even though this study is mainly focused on the effect of fishing, this is not the only ecological factor affecting MPAs performance; as well, their atmospheric variability and physical oceanography will also affect their performance, and the status of their ecosystem components and resources.

Historical catch reconstructions of exploited taxa from 1950 to 2018 are used to evaluate the effect of MPA and EEZ establishment on fishing intensity, expressed by catch tonnage that it generates. The country-by-country fisheries catch data reconstructions are based on a rationale [14] that was later operationalized for use in any country $[15,16]$. In addition, a one-question personalized questionnaire was sent to knowledgeable stakeholders to elicit perceptions of the fishing intensity within each MPA. This was corroborated by satellite imagery from the Global Fishing Watch (GFW).

The no-take LSMPAs that are evaluated here are the Papahānaumokuākea Marine National Monument (jointly with its 2016 expansion) in the Northwestern Hawaiian Islands (USA) and the Pitcairn Islands Marine Reserve (UK). The multi-use LSMPAs 
are the Galapagos Marine Reserve (Ecuador) and the Coral Sea Natural Park of New Caledonia (France).

The Papahānaumokuākea marine reserve is situated around the Northwestern Hawaiian Islands, and to native Hawaiians, it is where life originated and where spirits return to after death [17]. Efforts to protect this distinct cultural and ecological area date back to 1909, when its islets and reefs became the Hawaiian Islands Reservation. They were recognized as the Northwestern Hawaiian Islands Coral Reef Ecosystem Reserve in 2001 [18], and established as a Marine National Monument in 2006. The Papahānaumokuākea marine reserve became one of the largest and most strictly protected marine reserves in the world, and a model for the creation of marine reserves that protect cultural and ecological resources.

Pitcairn Islands, a UK territory surrounded by a marine ecosystem in nearly pristine conditions [19], began in 1989 when Henderson Island was declared as a UNESCO World Heritage Site. However, until 2012, the Pitcairn Island Council and the small island's community did not unanimously support the creation of a marine reserve around the Pitcairn Islands. Later, a proposal to establish the world's largest fully protected MPA was submitted to the U.K. government, and in January 2015, an experiment began to assess satellite monitoring of the Pitcairn EEZ [20]. The experiment was successful and led to the drafting of the Pitcairn Island MPA Ordinance and the LSMPA designation.

The Galapagos Islands are a province of Ecuador. The boundaries of the Galapagos Marine Reserve (GMR) were first designated in 1971 and the first marine protection was announced in 1986 [21]. However, its implementation did not get the support of the local population, whose rejection of measures proposed by the Galapagos National Park Services and the Darwin Biological Station repeatedly took very ugly forms [22,23]. In 1998, when the GMR was established (Table 1), it was one of the largest MPAs in the world. However, since its inception, it has been mired in issues related to different interests and power struggles [21]. To reduce conflicts, enhance sustainability and protect marine biodiversity [24], the first zoning plan was declared in 2000 and demarcated in 2006 [25].

In New Caledonia, a semi-autonomous overseas territory of France, efforts to protect the marine biodiversity date back to 1970, when a lagoon area was declared a marine reserve [18]. This was followed by the establishment of other marine reserves in 1990 [18]. In 2014, the French government decreed the creation of a "Coral Sea Natural Park" encompassing the entire EEZ of New Caledonia (Table 1). After extensive public consultations, a park management plan was approved and in 2018, the president of New Caledonia approved the Decree on the management plan 2018-2022 [26]. However, in 2020, a lawsuit by a fishing company caused a French court to declare the creation of the "Coral Sea Natural Park" null and void, because it was not based on New Caledonian legislation [27]. The required legislation was eventually passed by the New Caledonian parliament, but its implementation is delayed by local political squabbling.

This research adds another layer of knowledge to advance the use of more comprehensive data to consider more integrated management with stricter regulations and proper enforcement in multizone MPAs. More informed decision-making can conserve marine ecosystems and also protect small-scale fisheries and local economies that depend on these natural resources. In the following, we describe the approach and metrics we used to compare the performance of these four LSMPA within their EEZs to better inform conservation policy-making. 
Table 1. Basic features on the four large-scale marine protected areas covered in this study.

\begin{tabular}{|c|c|c|c|c|}
\hline $\begin{array}{l}\text { Item or } \\
\text { Property }\end{array}$ & $\begin{array}{l}\text { Papahānaumokuākea } \\
\text { + Expansion }\end{array}$ & $\begin{array}{l}\text { Pitcairn Islands } \\
\text { Marine Reserve }\end{array}$ & $\begin{array}{c}\text { Galapagos } \\
\text { Marine Reserve }\end{array}$ & $\begin{array}{c}\text { Coral Sea } \\
\text { Natural Park } \\
\text { New Caledonia }\end{array}$ \\
\hline EEZ designation year ${ }^{a}$ & 1983 & 1997 & 1952 & 1978 \\
\hline LSMPA stb year ${ }^{b}$ & $2006+2016$ & 2016 & 1998 & 2014 \\
\hline LSMPA area $\left(\mathrm{km}^{2} \cdot 10^{3}\right)^{\mathrm{b}}$ & 1493 & 833 & 138 & 1107 \\
\hline No-take area $\left(\mathrm{km}^{2} \cdot 10^{3}\right)$ & 1493 & 833 & $1.3^{c}$ & $54^{\mathrm{d}}$ \\
\hline$\%$ of EEZ protected & 94.6 & 99.6 & 16.6 & 77.8 \\
\hline$\%$ of EEZ with no-take & 94.6 & 99.6 & 0.2 & 3.8 \\
\hline Fisheries catch $\left(\mathrm{t} \cdot 10^{3}\right)^{\mathrm{e}}$ & 456 & 870 & 2121 & 829 \\
\hline Relative catch $\left(\mathrm{t} \cdot \mathrm{km}^{-2}\right)^{\mathrm{e}}$ & 0.29 & 1.04 & 2.54 & 0.58 \\
\hline
\end{tabular}

a Source: www.seaaroundus.org (accessed on 15 May 2021). ${ }^{b}$ Source: www.MPAatlas.com (accessed on 18 May 2021); for Hawaii, this refers only to the area around the Northwest Islands EEZ. ${ }^{c}$ Galapagos: based on digitizing maps in [28]; ${ }^{\mathrm{d}}$ New Caledonia: based on data from [29]. ${ }^{\text {e Source: } w w w . s e a a r o u n d u s . o r g ~(a c c e s s e d ~ o n ~} 15$ May 2021); catches from 1950 to 2018.

\section{Materials and Methods}

\subsection{Selection of the MPAs}

We selected four well-documented LSMPAs in the Pacific to compare the ecosystem response between a well-enforced EEZ and no-take or multi-use MPAs (Table 1), with (reconstructed) fisheries catches being the quantitative evidence used to assess the response.

In Papahānaumokuākea, commercial activities were banned, but light recreational and subsistence fishing was allowed. The site was designated as a mixed cultural and natural UNESCO World Heritage site in 2010. Ten years after the monument declaration, Papahānaumokuākea was expanded to the entire EEZ around the Northwestern Hawaiian Islands [30]. Designated as no-take area, the LSMPA occupies $15,082,511 \mathrm{~km}^{2}$ [31]. The area protects, inter alia, $2 \%$ of the world's seamounts [32] (www.seaaroundus.org; accessed on 15 May 2021), known for harboring high levels of biodiversity and endemicity [31].

Efforts to protect the isolated Pitcairn Islands began more than 30 years ago and resulted in the designation of $832,898 \mathrm{~km}^{2}(99.6 \%$ of the EEZ) as the Pitcairn Islands Marine Reserve in September 2016, where all extractive activities are prohibited [33]. The area is classified as no-take, and is thus considered in this study as a no-take LSMPA.

The Galapagos Marine Reserve (GMR) is the smallest of the present studied LSMPAs. It is a multi-use area of $137,975 \mathrm{~km}^{2}$ [21] with different zones, e.g., a no-take area of $1323 \mathrm{~km}^{2}$ [28] and conflicting objectives (artisanal fishing, tourism, and conservation). New zoning arrangements were proposed in 2016, but not implemented until 2019 [21]. This new zoning and potential benefits of it are not explored in this study.

The Coral Sea Park was conceived, and is likely to remain, as a multi-use LSMPA which occupies 1,100,210 $\mathrm{km}^{2}$ of New Caledonian waters (77.3\% of the EEZ) with a no-take area of $53,862 \mathrm{~km}^{2}$ [29].

\subsection{Sources of Reconstructed Catches}

Reconstructed fisheries catches are based on official catches generated by national agencies that are reported to the Food and Agriculture Organization of the United Nations (FAO) [34], but which are complemented by catches that are omitted in official statistics [14,35]. Procedures used for reconstructions operationalized in $[15,36]$ were applied and the details of these reconstructions are provided in the references cited in Table 2. The time series of reconstructed catch data from the Sea Around Us database [37] allocated to half degree cells provided a measure of the tonnage of exploited biodiversity for the EEZs of the LSMPAs listed in Table 1. Catches are from industrial, artisanal, subsistence and recreational fisheries, without focusing on a single gear. Foreign catch is understood here as the catch by vessels with a flag other than the sovereign country, i.e., the US for the Northwest Hawaiian Islands, Ecuador for the Galapagos, the UK for Pitcairn and France for New Caledonia. 
Table 2. Publication in which the reconstructions are presented which yielded the catch data used here.

\begin{tabular}{ccccc}
\hline $\begin{array}{c}\text { Period } \\
\text { Covered } \\
\text { (and Remark) }\end{array}$ & $\begin{array}{c}\text { Papahānaumokuākea } \\
\text { + Expansion }\end{array}$ & $\begin{array}{c}\text { Pitcairn } \\
\text { Islands } \\
\text { Marine } \\
\text { Reserve }\end{array}$ & $\begin{array}{c}\text { Galapagos } \\
\text { Marine } \\
\text { Reserve }\end{array}$ & $\begin{array}{c}\text { Coral Sea } \\
\text { Natural Park } \\
\text { New Caledonia }\end{array}$ \\
\hline From 1950 to various & 2002 & 2009 & 2010 & 2007 \\
years & {$[36,38,39]$} & {$[40]$} & {$[41,42]$} & {$[43]$} \\
Update to 2010 & {$[15,44]$} & {$[45]$} & {$[42]$} & {$[49]$} \\
Update to 2018 & {$[47]$} & {$[48]$} & {$[48]$} \\
\hline
\end{tabular}

${ }^{\text {a }}$ See also [50].

\subsection{Fishing down the Food Web}

The impact of fisheries on the resources of two LSMPAs which currently continue to be exploited commercially, i.e., the EEZs of New Caledonia and the Galapagos Islands, was quantified using the Marine Trophic Index (MTI), i.e., the mean trophic level of fish and invertebrates in the catch [51,52]. The MTI document shifts in fisheries catches, from large, high-trophic level, to small, lower-trophic level species, i.e., assessing ecological shifts in the species landed.

For New Caledonia, the method of Kleisner et al. [53] was used to account for the geographic expansion of the fisheries, a major cause of bias in interpreting time series of MTI [54]. For Galapagos, we applied the approach of Schiller et al. [41], which explicitly accounted for the taxonomic distinction between inshore and offshore taxa. This avoided an ill-defined ecosystem that combined species which do not interact with each other [41].

\subsection{Fishing the Line}

Maps illustrating the propensity of fishing vessels to operate along the edge of MPAs, marine reserves or other areas with higher resource biomass, and with a tendency to 'spill over' their border [55-57] were extracted from the Global Fishing Watch (GFW) database [58], covering a 6-month period in 2018 around the Galapagos.

\subsection{Questionnaires to Stakeholders}

As part of a global assessment of the perceived effectiveness of MPAs throughout the world, 150 personal emails were sent between February 2020 and June 2021. These emails were sent to different stakeholders that are in a close relationship with the MPA, i.e., members of the scientific and NGOs communities, journalists and government staff in the four island groups. Scientists, NGO staff and journalists were selected based on their publications. Within governments, we aimed at staff or managers from environmental departments. The only question was whether a given MPA was being fished, i.e., respondents were asked to choose between 'no fishing', 'light fishing', 'moderate fishing' and 'very intense fishing'; respondents were also invited to provide further comments. We are aware of the importance of fishers' opinions towards MPAs and that their role should be considered [59]; however, fishers' replies were not added in the results of this paper due to their low response rate. The UBC Office of Research Ethics approved this research and its ethics (ID \#: H19-03029).

\section{Results}

\subsection{EEZ Effect on Total Catch}

Foreign catches declined radically following EEZ implementation in the Northwestern Hawaiian Islands, Pitcairn and New Caledonia (Figure 2). These three EEZs belong to the US, UK and France, i.e., entities with the means to suppress foreign fishing. In the Northwestern Hawaiian Islands and Pitcairn, this resulted in a radical reduction of catches, while in New Caledonia, this resulted in a replacement of foreign catches by local catches. 
This confirms that establishing clear property rights of fisheries resources through EEZs allows effective governance of fisheries [60].

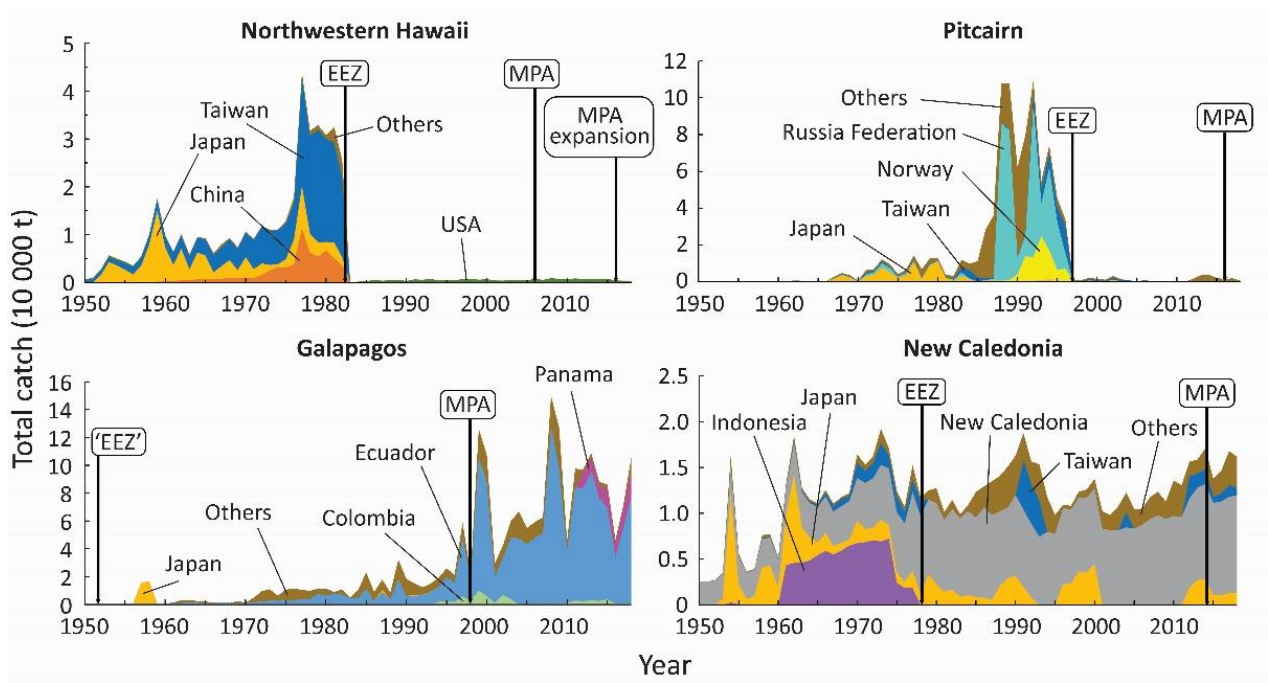

Figure 2. Total catch from 1950 to 2018 (extracted from the Sea Around Us database; www. seaaroundus.org, accessed on 10 of February 2021) at the four study sites, showing main fishing countries. The early 'EEZ' declaration by Ecuador was unilateral and did not conform with international laws at the time.

In the Northwest Islands of Hawaii and Pitcairn Islands, the annual catch gradually grew since the 1950s until it dropped by $91 \%$ in 1983 in Hawaii and by $94 \%$ in 1996 in the Pitcairn Islands. The decade-long increases in catch since the 1950s were the result of the global buildup and expansion of fishing effort throughout the world's oceans, particularly the Pacific [61,62]. The rapid decrease of the total catch in both sites coincided with the establishment of an EEZ, and was indeed one of its results (Figure 2, upper panels. There, before the EEZ establishment, many different fishing entities contributed to the overall catch. However, since the EEZ establishment, the local fleets dominate.

Before the EEZ establishment around the Hawaii Northwest Islands, nearly $90 \%$ of the tonnage taken was caught by three foreign fleets, i.e., those of Taiwan, Japan and China (Table 3). In the Pitcairn Islands, before the EEZ establishment, more distant-fishing foreign entities frequented the fishing grounds. Since the 1970s, European and Asian fleets began facing restricted access to formerly openly accessible coastal waters. Exclusion as well as complicated negotiations for EEZ quota agreements with sovereign countries led some fleets to seek alternative, more distant waters [1], mainly in the southern hemisphere [63].

Table 3. Top three entities with fishing fleets operating (or having operated) within the EEZ between 1950-2018. Range of years in bracket indicate the bulk of the catch.

\begin{tabular}{|c|c|c|c|}
\hline $\begin{array}{c}\text { Northwestern } \\
\text { Hawaii } \\
(1958-1980)\end{array}$ & $\begin{array}{c}\text { Pitcairn } \\
(1970-1996)\end{array}$ & $\begin{array}{c}\text { Galapagos } \\
(1998-2018)\end{array}$ & $\begin{array}{c}\text { New Caledonia } \\
(1960-2018)\end{array}$ \\
\hline Taiwan $(48 \%)$ & Russia (44\%) & Ecuador $(72 \%)$ & New Caledonia (57\%) \\
\hline Japan $(26 \%)$ & Japan $(10 \%)$ & $\begin{array}{l}\text { Unknown country } \\
(17 \%)\end{array}$ & Japan (15\%) \\
\hline China $(14 \%)$ & Norway $(10 \%)$ & Panama (4\%) & Indonesia (11\%) \\
\hline
\end{tabular}

The waters around Galapagos are at the confluence of three major ocean currents [26], and they are very productive [64]. However, this is not the only reason why the Galapagos Islands have the highest overall catch among the four sites (Table 1). The other reason is that the Ecuadorian mainland fleet operates within the Galapagos EEZ. 
Contrary to what occurs around the Pitcairn and Hawaiian Islands, in the cases of the Galapagos Islands and New Caledonia, as may be visually assessed in Figure 2, the establishment of EEZs does not coincide with any change in total catch. Instead, the catch increases over time, independently of EEZ establishment.

In Galapagos EEZ the major component of these catches is generated by the industrial sector. Of the 56 commercially caught species, 5 represent $89 \%$ of the total catch: skipjack tuna, Katsuwonus pelamis (40\%), yellowfin tuna, Thunnus albacares (20\%), Humboldt squid, Dosidicus gigas (16\%), bigeye tuna, Thunnus obesus (10\%) and blue shark, Prionace glauca. In New Caledonia, the industrial sector contributes $52 \%$ of a catch composed of 119 taxa. Of the catch identified to species level, three dominate overall, albacore tuna Thunnus alalunga (12\%), spangled emperor Lethrinus nebulosus (7\%) and yellowfin Thunnus albacares (5\%).

On the other hand, in the multi-zone LSMPA of Hawaii, the catch is predominantly recreational (65\%). The top 5 of the 171 commercially caught taxa in Hawaii represent $55 \%$ of the total catch: mahi-mahi Coryphaena hippurus $(14 \%)$, yellowfin tuna Thunnus albacares (13\%), skipjack tuna Katsuwonus pelamis (11\%), with the nondescript group "marine fishes not identified" making up almost 11\%, and the scad Selar crumenophthalmus (7\%). Conversely, in Pitcairn, most of the fishing that historically took place was undertaken by the industrial sector $(99.96 \%)$. Most of this catch was reported as "marine fishes not identified" (92\%), which only a small percentage attributed to species, notably yellowfin tuna Thunnus alalunga and bigeye tuna Thunnus obesus.

\subsection{Effects of MPA Declaration on Fisheries}

The creation of Papahānaumokuākea in 2006 had minimal impact on total catches because only a few lobster boats based in the main Hawaiian Islands were licensed to operate within the Northwestern Hawaiian Islands. The US tuna fleet, which operated before the extension of Papahānaumokuākea in waters extending from 50 to 200 miles (i.e., the entire EEZ), was also minimally affected because the catches from these areas were a very small fraction of their total withdrawals [65]. In fact, there is not much fishing around Papahānaumokuākea (Figure 3A).

Similarly, the declaration of the MPA had no noticeable effect on the catch around the Pitcairn Islands (Figure 3B) and New Caledonia (Figure 3C), albeit for different reasons. In the Pitcairn Islands (where the MPA was created in 2016), foreign fleets were already absent since the declaration of the EEZ in 1997. On the other hand, in New Caledonia, the MPA declaration (which covered almost the entire EEZ) was not followed by any measure designed to limit fishing operations in what is supposed to be the "Parc Naturel de la Mer de Corail." Indeed, fishing effort increased in the 'Parc Naturel' since it was created [66-68]. The Government of New Caledonia appears oblivious to the fact that extractive activities must be limited for an MPA to be recognized as such, e.g., by IUCN [69].

It is in the Galapagos Archipelago that the situation is most complex (Figure 3D). Even though the no-take areas only occupy $1 \%$ of the MPA (or $0.2 \%$ of the EEZ), the lack of consultation and participation of the small-scale fishers during the MPA creation has led to many disputes [70]. This resulted in conservation efforts having little support on the island, despite the dependence of Galapagos' economy on tourism, which itself depends on a healthy marine ecosystem [64]. 


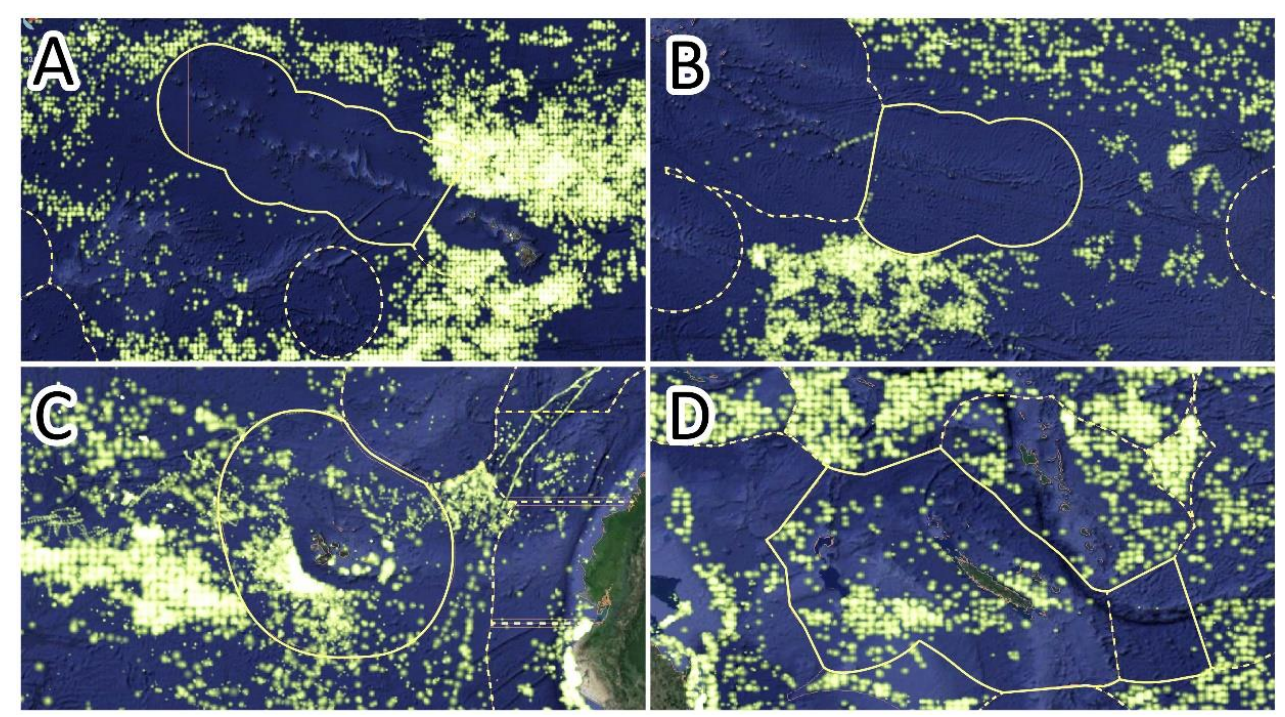

Figure 3. Fishing by recorded vessel effort in the four study sites: (A) Northwest Islands of Hawaii, (B) Pitcairn, (C) Galapagos and (D) New Caledonia. The yellow dots and the intensity of the yellow color reflect the distribution of fishing effort. Extracted from the latest data of the GFW AIS-based fishing effort and vessel presence datasets. Based on the detections of $>114,000$ unique AIS devices on fishing vessels, of which $\sim 70,000$ are active each year. Source: Global Fishing Watch data from January 2018 to July 2018 [71].

The fisheries resources in Ecuador's EEZ around Galapagos experience pressure by five fisheries:

(1) An artisanal fishery by about 1000 fishers (98\% men; [72]) residing in the Galapagos Islands;

(2) A tourist-based recreational fishery;

(3) A legal industrial fishery by industrial vessels from the Ecuadorian mainland;

(4) Illegal foreign fishing;

(5) Large foreign (mainly Chinese) fisheries just outside the EEZ, relying on species that, to a large extent, will complete their life cycle within the Galapagos EEZ.

The fishers in (1) are the descendants of several waves of settlers from the Ecuadorian mainland, the most important of which started illegally in 1991 and legally in 1994 in the heydays of the short-lived fishery for sea cucumbers [73,74]. Most of these fishers, and their sons, want to be able to fish as along the Ecuadorian mainland, i.e., without restrictions, and are reluctant to accept that they operate within an MPA. They are also largely unaware of the dependency of the economy of the Galapagos Islands on tourism, and hence the frequent conflicts between fishers and the authorities [64,73].

As a result of the failure to effectively restrict artisanal fishing, overexploited species of reef fish and invertebrates, such as the red spiny lobster, have not recovered despite years of legal protection [75]. Since 1971, catches gradually increased, peaked in 2008, and fluctuated since (Figure 2). Many artisanal fishers now also engage in longline fishing, which reduces the population of large pelagic fish that are part of what makes Galapagos attractive to dive tourism [76].

The fishery in (2) is supposed to be a catch-and-release fishery [77]. However, 'playing' with large pelagic fish stresses them, notably by increasing the lactate content of their blood [78], and few of the fish released survive the ordeal [79,80].

The Ecuadorian fishery (3) in the EEZ of Galapagos is described in [42,74,81-84]. The major species targeted are tunas (Thunnus albacares, T. obesus and Katsuwonus pelamis), groupers (Mycteroperca olfax, Paralabrax albomaculatus and Epinephelus labriformis), other bony fishes (Caulolatilus princeps and Pontinus clemensi) and invertebrates such as sea cucumber (Isostichopus fuscus) and lobsters (Panulirus penicillatus and P. gracilis). 
Some of the foreign fishing countries in Figure 2 (lower left panel), such as Colombia, Japan, Costa Rica, Taiwan and South Korea, have been involved in illegal longline fishing around the Galapagos (4). There is a case where the flesh of the (highly protected) Galapagos sea lion was used as bait to catch sharks for finning, while only operating on a license for tuna [85].

The large foreign fishery (5) pertains mainly to a large Chinese squid fishery that operates in the high seas outside of the Galapagos [86,87]. Media complaints about this fishery were largely disingenuous, as they singled out this fishery, which was legal. Moreover, the vessels in question did not appear to have been dashing in and out of the EEZ, as often appears when 'fishing the line' (see below), and also appear to have followed new guidelines from the Chinese Government to remain $15 \mathrm{~nm}$ (nautical miles, i.e., $27.8 \mathrm{~km}$ ) from the EEZ border. Nevertheless, the large catch by this fleet $[85,86]$ likely impacted the squid stock in question, as it can be expected to straddle the EEZ border. Debates about this fleet are thus better conducted in a frame of discussion to protect marine resources in the high seas, i.e., to reduce or abolish fishing therein $[88,89]$.

\subsection{Fishing down Marine Food Webs}

Both New Caledonia and the Galapagos Islands exhibit a decline of the mean trophic level of the fish that they exploit, suggesting a gradual erosion of their resource base (Figure 4). In both cases, the decline of mean trophic levels (TLs) was more pronounced inshore than offshore, which is to be expected, given that there are fewer small, low-trophic level species offshore than inshore. In the Galapagos, this effect was enhanced by the rush for, and huge catch of the brown sea cucumber (Isostichopus fuscus) from the mid-1980s to the late 2000s. Sea cucumbers (including the brown sea cucumber), feed on bottom detritus (with a definitional $\mathrm{TL}=1$ ) and their associated microfauna, and thus have a low trophic level of about 2.1 [90]. Large catches of the brown sea cucumber will thus tend to reduce mean trophic level, if only temporarily.

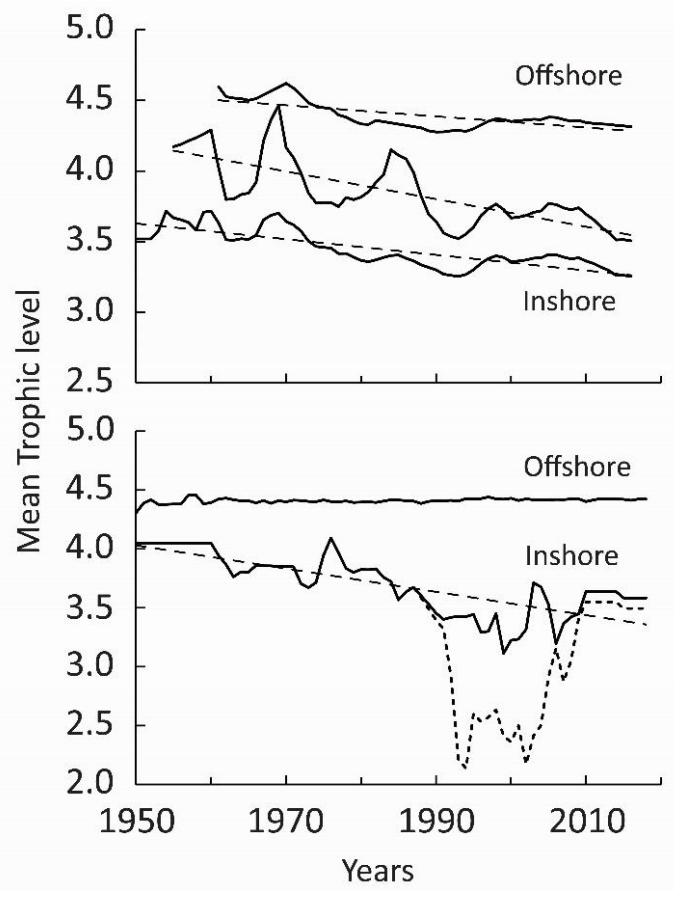

Figure 4. Changes in mean trophic level (TL) of the catch, or Marine Trophic Index (MTI) from 1950 to 2018 in the New Caledonia EEZ (top panel) and the Galápagos Islands EEZ (bottom panel). In New Caledonia, the rate at which the inshore, intermediate and offshore MTI (estimated using the method of Kleisner et al. [53]) was 0.056, 0.098, and 0.039 TL per decade; in Galapagos, the inshore TL trend, estimated using the criteria in Schiller et al. [41] was 0.099 per decade if the temporary dip in TL caused by the sea cucumber fishery (dotted line) is ignored. 


\subsection{Fishing the Line}

Figure 5 illustrates two levels of 'fishing the line' around the Galapagos Islands. The first level is represented by non-Ecuadorian vessels fishing at the southern edge of the Galapagos EEZ (Figure 5A). Operations of this sort by a Chinese squid fleet were the subject of intense, negative international press coverage (see above). Figure $5 \mathrm{~B}$ documents fishing at the edge of the Galapagos LSMPA, i.e., within the Galapagos EEZ, by Ecuadorian vessels and vessels from other countries presumed to have access agreements to the Galapagos EEZ.

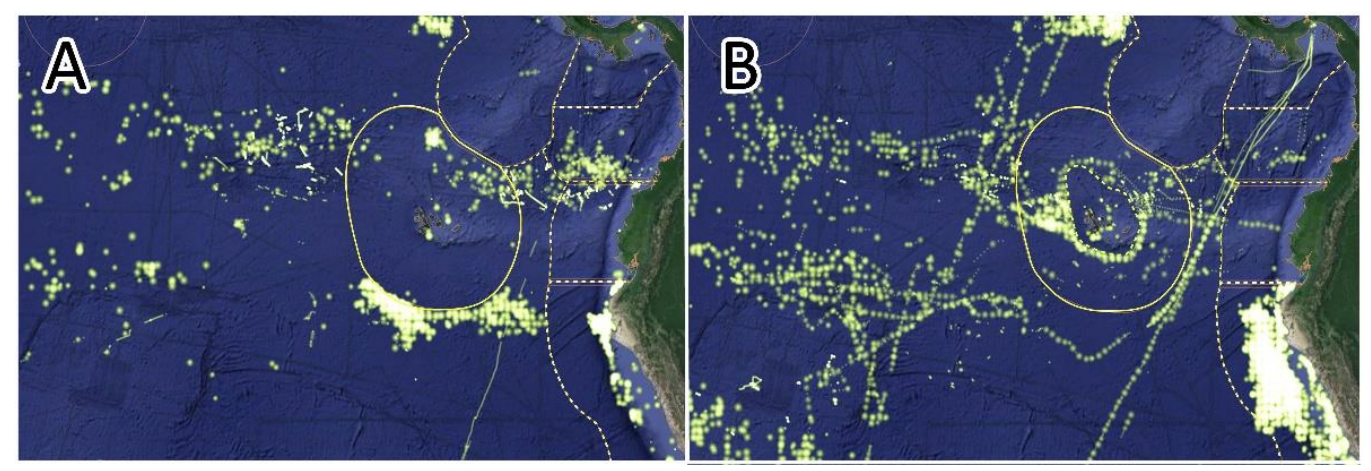

Figure 5. Fishing the line in the Galapagos is shown with yellow dots that represent fishing effort. (A): Demonstrates fishing the line in the EEZ of Galapagos in September 2020. (B): Shows fishing the line around the Galapagos Marine Reserve in December 2019 [71].

Note that only a small fraction of the Galapagos LSMPA is no-take (Table 1). Thus, Ventura et al. [91] suggested protecting the western coast of Fernandina and Isabela Islands and their endemic vertebrates, such as Galapagos penguins (Spheniscus mendiculus), flightless cormorants (Phalacrocorax harrisi) and the local invertebrates that provide food to the resident fur seals and the seabirds that breed in that area.

In addition, also note that the non-occurrence of fishing the line not necessarily implies that a marine reserve or MPA was badly designed because it does not generate a 'spillover'. Rather, it may be due to the border area of the marine reserve or MPA having a low productivity or not including desired habitats [92]. For example, spill-over around the Papahānaumokuākea Marine National Monument is not expected as there are no nurseries or spawning grounds around the LSMPA for the target species of the Hawaiian longline fishery [93].

\subsection{Stakeholder Opinions}

Out of 150 emails sent to the different stakeholders to assess the level of fishing at the four sites, 20 did not reach their intended recipient, and 17 responses provided information that was not relevant. Only 42 replied to the question (Table 4).

The fishing effort observed in Figure 3 matches the stakeholders' responses to inquiries on the intensity of fishing from our questionnaire. Table 5 presents a sample of some of the replies that confirmed the impressions summarized in Table 1. 
Table 4. Response ratios by occupation of stakeholder respondents for each site (response received/emails sent).

\begin{tabular}{cccccc}
\hline LSMPA & Acad. & Gov. & Journ. & NGO & $\begin{array}{c}\text { Most Common } \\
\text { Response }\end{array}$ \\
\hline $\begin{array}{c}\text { Papahanaumokuakea } \\
\text { Monument }\end{array}$ & $5 / 9$ & $5 / 11$ & $1 / 10$ & $0 / 5$ & No fishing \\
$\begin{array}{c}\text { Pitcairn Islands } \\
\text { Galápagos Marine }\end{array}$ & $7 / 10$ & $1 / 2$ & $1 / 6$ & $0 / 4$ & Light fishing \\
$\begin{array}{c}\text { Reserve } \\
\text { Natural Park of the }\end{array} \quad 7 / 15$ & $0 / 8$ & $1 / 6$ & $3 / 8$ & Moderate fishing \\
Coral Sea & $3 / 10$ & $4 / 11$ & $1 / 6$ & $3 / 9$ & Light fishing \\
\hline
\end{tabular}

Table 5. Example of responses from the different stakeholders at the study sites.

LSMPA Comment

"No fishing (not legally and no evidence as far as I know for any US vessels fishing there based on Global Fish watch)" Academic-April 2020.

"No commercial fishing is allowed. Indigenous/traditional and non-commercial fishing activities, as well as permitted research involving extraction are allowed. Although I don't

Hawaii know at what level the latter activities actually take place, given the remoteness of the monument I will select: Light fishing" Government-March 2020.

"[ . . ] From what I have reported, there seemed to be minimal fishing there $(8 \%$ perhaps of bigeye catch?) and when the monument expanded, those fishers likely just went elsewhere as overall catch has remained the same or grown since the expansion" Journalist-April 2021.

"[ ... there is a limited amount of fishing for subsistence still ongoing on Pitcairn Island-I do get a regular update from some of the islanders-so probably record it as 'light fishing'-but not for commercial enterprise!" Academic-April 2020.

“We didn't observe any fishing boats in the MPA, we did however find a lot of fishing

Pitcairn aggregation devices washed up on Henderson Island. [ . . . ] So hard to know because I don't

Islands $\quad$ know where the devices floated from. I'd say they are at least moderately targeting the MPA by floating the devices through them to pull fish out to the edge" NGO-March 2021.

"Pitcairn MPA: light fishing. There is of course some subsistence fishing from the island's 46 residents, but at a Pitcairn Environment Group meeting just last week, a presentation on satellite monitoring of AIS signals indicated no ships inside the EEZ" Academic-April 2021. "[ ... T The number of active fishers and vessels has shown a declining trend since 2002 due to several socioeconomic factors, including the total closure of the sea cucumber fishery, the global financial crisis 2007-09, and the aging of local small-scale fishers. Based on this information, in my opinion, the level of fishing in the Galapagos Marine Reserve, before the COVID-19, was moderate. Since 16 March a lockdown was established in Galapagos. Since then, commercial flights were prohibited and the number of tourists has declined to zero for the first time in the history of the archipelago. In consequence, most fishers stopped their fishing operations as there are not places to sell their landings. Some fishers remain fishing to fulfill local seafood demand. [ ... ]" Academic-April 2020.

Galapagos "To answer your question, I would say levels are moderate, amongst the artisanal fishing fleet that is permitted to fish inside the Galapagos Marine Reserve" Academic-May 2020. "[ ... ] Unfortunately, it's not a straightforward answer. If you refer to the coastal resources around the islands, I would tick the moderate fishing box, because the local artisanal fleet has brought the sea cucumber to commercial collapse and has likely overexploited lobster and grouper. If you refer to open water fishing then I would tick the 'light fishing' box, as the effort in relation to the industrial and semi-industrial fleets outside the reserve is very small. If forced to choose an overall figure, I'd find it tough, but would probably have to pop for 'moderate' to reflect the impact on the coastal resources. [ . . . ]" Academic-June 2021. "I would consider that current fishing level in the Natural Park of the Coral Sea in NC is Moderate fishing. [ ... ] So yes, fishing is happening (and probably because of that it should not be called an MPA, but a marine managed area), but I believe it is moderate and it is controlled" NGO-April 2021.

\section{Discussion}

Here, we showed that well-enforced EEZs allow for effective governance and protection of marine resources [94]. In Pitcairn and the Northwest islands of Hawaii, the establishment of EEZs had a strong effect on fisheries, directly and substantially reducing 
foreign industrial fishing. Therefore, the subsequent impact of the LSMPA establishment on catches was very small in both Northwestern Hawaii and Pitcairn.

We found that in multizone LSMPAs, neither the EEZ nor the MPA establishment produced a change in the total catch over time. Our results also demonstrate that in multizone LSMPA, neither the EEZ or MPA establishment changed the total catch. Instead, fishing down marine food webs is evident. This is a starting point to advance the use of more comprehensive data for more integrated management, stronger regulations and proper enforcement in multizone MPAs.

Marine protected areas (MPAs) and exclusive economic zones (EEZs) have the potential to protect marine ecosystems. However, the exploitation of marine resources has been continuously increasing since the 1950s, driven by the geographical and technological expansion of the fishing industry [62].

As a result of the United Nations Convention on the Law of the Sea [95], coastal states can claim an exclusive economic zone (EEZ) which extends to 200 nautical miles from their shores. Under Article 56 of UNCLOS, coastal states have an exclusive right to exploit or conserve both living resources, such as fish, and non-living resources, such as oil and natural gas within this zone. Article 56 also mentions explicitly the possibility of establishing MPAs [60].

The operations of industrial fisheries within an EEZ can cause substantial damage to the biodiversity therein. However, satellite-based monitoring allows cost-effective tracking of industrial fishing vessels. Thus, if all maritime countries were to be prodded by the International Maritime Organization to force their industrial vessels to carry an automatic identification system (AIS), monitoring and surveillance would be straightforward [96]. For example, in Galapagos, satellite information helped spot the vessel Fu Yuan Yu Leng 999, which entered the protected waters of the Galapagos Marine Reserve (GMR) in August 2013 with thousands of sharks and shark fins on board. This refrigerated cargo vessel was involved in illegal transshipments from tuna long-liners in the equatorial eastern Pacific [71].

Currently, as one of the NGO respondents to our questionnaire suggested (June 2021), "the GMR is one of the MPAs with the best technological control and surveillance systems. However, there are other external factors that affect us, such as the fish aggregating devices (FADs) used by the tuna purse seine industry. Those devices are placed outside the GMR, but by the currents [bring them into] the reserve and when they leave, they remove biomass from the reserve. There are also minor impacts from local artisanal fishing, with prohibited gear such as longlines". The same modus operandi of deploying FADS to pull fish out the MPA was also reported in Pitcairn by an NGO (March 2021, stakeholders opinion questionnaire).

Global catches have been declining since 1996 [16], which highlights the importance of rebuilding stocks in the waters of both developed and developing countries. This overall decline of catch is not due to a decline in fishing effort or to the establishment of marine reserves. Rather, it is due to excessive fishing pressure on fish populations globally [97], notwithstanding stock rebuilding in the EEZ of a few countries that are enlightened in this regard, notably the US and Norway [98-102].

Stock rebuilding can be aided by establishing MPAs that offer high levels of protection and networks among them. However, MPAs and similar place-based tools for protecting marine biodiversity will have ecological and social benefits only if fishing regulation, monitoring and enforcement are not undermined by political sort-termism [103] and are ecologically coherent.

In New Caledonia, the EEZ implementation resulted in foreign fleets being replaced by a local industrial fleet, as was also the case in Canada [104]. The subsequent designation of the entire EEZ as a huge MPA, the 'Parc Naturel de la Mer de Corail' has no effect whatsoever on catches, because it is in effect a 'paper park', involving no restriction on the operation and growth of the local industrial fishery. Fortunately, the local demand for livelihoods and fish, and the export potential are limited, thus for the time being, 
preventing fishing pressure to grow as it does within Galapagos. In this territory the migration of landless farmers and impoverished fishers from the Ecuadorian mainland, who found themselves unemployed when the sea cucumber boom led to a predictable collapse of the brown sea cucumber population. Indeed, this is a major element of the perennial issues of fisheries management in Galapagos [64,73]. We showed that satellite monitoring and perception surveys of various stakeholder groups can support each other in evaluating the performance of MPAs. Thus, it appears that we possess the legal, technical and conceptual tools to protect marine biodiversity via LSMPAs, which work as long as stakeholder involvement is duly considered [105-107]. The point is to use these tools.

One of the differences between establishing an EEZ and an MPA is that most new MPAs are founded on scientific research of the area, for example biodiversity assessments $[108,109]$ or anthropogenic threat evaluations $[110,111]$. This is already a very positive aspect of establishing integrated, well-designed and connected MPAs. The more information there is about a sea area, the coastal populations and their socio-ecological relationships, the better stressors, systemic impacts and inter-annual variabilities can be identified [112]. Data is vital to inform policy commitments around ocean protection and rebuild ocean life [113]. Once again, we want to stress that, even though we do not observe positive or direct changes after no-take or multi-use MPAs establishment, we must not underestimate the value of and need for MPAs that offer equitable access of resources to locals, high levels of protection and that cover a representative set of marine habitats such that biodiversity is maintained.

Author Contributions: V.R., M.L.D.P. and D.P. conceived the idea of evaluating and comparing the marine biodiversity and fisheries of large marine protected areas with focus on areas that were considered by the Pew Charitable Trusts for conservation initiatives. V.R. improved (by adding the interview part and extracting the satellite imagery) and implemented the research plan and analyzed the fisheries catch data. V.R. wrote the first draft, which D.P. and M.L.D.P. edited. All authors have read and agreed to the published version of the manuscript.

Funding: This study was funded by the Pew Charitable Trusts.

Institutional Review Board Statement: The study was conducted according to the guidelines of the University of British Columbia and approved by the UBC Behavioural Research Ethics Board (the Ethics ID Number is H19-03029 and date of approval is 29 November 2019).

Informed Consent Statement: Written informed consent has been obtained from all the respondents to use their input in our study, if anonymized.

Data Availability Statement: Data are available upon request.

Acknowledgments: We thank the respondents to our email surveys, Elaine Chu for drafting our figures, Martin Nevado and Elisabeth David for data extraction and map assistance. The Sea Around Us is a research initiative supported by the Oak Foundation, David and Lucille Packard Foundation, Marisla Foundation, Minderoo Foundation, Paul M. Angell Family Foundation, MAVA Foundation, Oceana and RARE. The project that gave rise to these results received the support of a fellowship from "la Caixa" Foundation (ID 100010434). The fellowship code is LCF/BQ/AA18/11680035.

Conflicts of Interest: The authors declare no conflict of interest. The funders had no role in the design of the study; in the collection, analyses, or interpretation of data; in the writing of the manuscript, or in the decision to publish the results.

\section{References}

1. Watson, J.; Dudley, N.; Segan, D.B.; Hockings, M. The performance and potential of protected areas. Nature 2014, 515, 67-73. [CrossRef] [PubMed]

2. Wood, L.J.; Fish, L.; Laughren, J.; Pauly, D. Assessing progress towards global marine protection targets: Shortfalls in information and action. Oryx 2008, 42, 340-351. [CrossRef]

3. Boonzaier, L.; Pauly, D. Marine protection targets: An updated assessment of global progress. Oryx 2015, 50, 27-35. [CrossRef]

4. Dudley, N. (Ed.) Guidelines for Applying Protected Area Management Categories; IUCN: Gland, Switzerland, $2008 ;$ p. 86.

5. Costanza, R.; D’Arge, R.; De Groot, R.; Farber, S.; Grasso, M.; Hannon, B.; Limburg, K.; Naeem, S.; O’Neill, R.V.; Paruelo, J.M.; et al. The value of the world's ecosystem services and natural capital. Nature 1997, 387, 253-260. [CrossRef] 
6. Lubchenco, J.; Palumbi, S.R.; Gaines, S.D.; Andelman, S. Plugging a hole in the ocean: The emerging science of marine reserves. Ecol. Appl. 2003, 13 (Suppl. 1), 3-7. [CrossRef]

7. Postel, S.L.; Thompson, B.H., Jr. Watershed protection: Capturing the benefits of nature's water supply services. Nat. Resour. Forum 2005, 29, 98-108. [CrossRef]

8. Lester, S.E.; Halpern, B.S.; Grorud-Colvert, K.; Lubchenco, J.; Ruttenberg, B.; Gaines, S.D.; Airamé, S.; Warner, R. Biological effects within no-take marine reserves: A global synthesis. Mar. Ecol. Prog. Ser. 2009, 384, 33-46. [CrossRef]

9. Leenhardt, P.; Cazalet, B.; Salvat, B.; Claude, J.; Feral, F. The rise of large-scale marine protected areas: Conservation or geopolitics? Ocean Coast. Manag. 2013, 85, 112-118. [CrossRef]

10. Artis, E.; Gray, N.J.; Campbell, L.M.; Gruby, R.L.; Acton, L.; Zigler, S.B.; Mitchell, L. Stakeholder perspectives on large-scale marine protected areas. PLoS ONE 2020, 15, e0238574. [CrossRef]

11. De Santo, E.M. Militarized marine protected areas in overseas territories: Conserving biodiversity, geopolitical positioning, and securing resources in the 21st century. Ocean Coast. Manag. 2020, 184, 105006. [CrossRef]

12. Devillers, R.; Pressey, R.L.; Grech, A.; Kittinger, J.N.; Edgar, G.J.; Ward, T.; Watson, R. Reinventing residual reserves in the sea: Are we favoring ease of establishment over need for protection? Aquat. Conserv. 2015, 25, 480-504. [CrossRef]

13. White, T.D.; Ong, T.; Ferretti, F.; Block, B.A.; McCauley, D.J.; Micheli, F.; De Leo, G.A. Tracking the response of industrial fishing fleets to large marine protected areas in the Pacific Ocean. Conserv. Biol. 2020, 34, 1571-1578. [CrossRef]

14. Pauly, D. Rationale for reconstructing catch time series. EC Fish. Coop. Bull. 1998, 11, 4-7.

15. Zeller, D.; Harper, S.; Zylich, K.; Pauly, D. Synthesis of under-reported small-scale fisheries catch in Pacific-island waters. Coral Reefs 2015, 34, 25-39. [CrossRef]

16. Pauly, D.; Zeller, D. Catch reconstructions reveal that global marine fisheries catches are higher than reported and declining. Nat. Commun. 2016, 7, 10244. [CrossRef] [PubMed]

17. Kikiloi, K. Reconnecting with Ancestral Islands: A Guide to Papahānaumokuākea (the Northwestern Hawaiian Islands). In Detours: A Decolonia guide to Hawai'I; Aikau, H.K., Gonzalez, V.V., Eds.; Duke University Press: New York, NY, USA, 2020; pp. 380-390.

18. Claudino-Sales, V. Springer Earth and Environmental Science eBooks 2019 English/International \& SpringerLink (Online service) 2019. In Coastal World Heritage Sites, 1st ed.; Springer: Dordrecht, The Netherlands, 2019. [CrossRef]

19. Friedlander, A.M.; Caselle, J.E.; Ballesteros, E.; Brown, E.K.; Turchik, A.; Sala, E. The Real Bounty: Marine Biodiversity in the Pitcairn Islands. PLoS ONE 2014, 9, e100142. [CrossRef] [PubMed]

20. Pew Charitable Trusts. Effective Surveillance in the Waters of the Pitcairn Islands Marine Reserve-Monitoring Vessel Activity in One of the Most Remote Areas on Earth. A Fact Sheet from the PEW Trusts. 2016. Available online: https:/ /www.pewtrusts.org/ - / media/assets/2016/09/effectivesurveillanceinthewatersofthepitcairnislandsmarinereserve.pdf (accessed on 1 July 2020).

21. Burbano, D.V.; Meredith, T.C.; Mulrennan, M.E. Exclusionary decision-making processes in marine governance: The rezoning plan for the protected areas of the 'iconic' Galapagos Islands, Ecuador. Ocean Coast. Manag. 2019, 185, 105066. [CrossRef]

22. Brown, P. Scientists Held Hostage on Darwin's Island. The Guardian. 28 February 2004. Available online: https://www. theguardian.com/world/2004/feb/28/highereducation.fishing (accessed on 10 May 2021).

23. Oviedo, P. The Galápagos Islands: Conflict management in conservation and sustainable resource management. In Cultivating Peace: Conflict and Collaboration in Natural Resource Management; IDRC: Ottawa, ON, Canada, 1999; pp. 163-182.

24. Heylings, P.; Bensted-Smith, R.; Altamirano, M. Zonificación e historia de la Reserva Marina de Galápagos. In Reserva Marina de Galápagos_Linea Base de La Biodiversidad; Danulat, E., Edgar, G.J., Eds.; Fundación Charles Darwin y Servicio Parque Nacional de Galápagos: Santa Cruz, CA, USA, 2002; pp. 10-22.

25. Castrejón, M.; Charles, A. Improving fisheries co-management through ecosystem-based spatial management: The Galapagos Marine Reserve. Mar. Policy 2013, 38, 235-245. [CrossRef]

26. Payri, C.E.; Allain, V.; Aucan, J.; David, C.; David, V.; Dutheil, C.; Loubersac, L.; Menkes, C.; Pelletier, B.; Pestana, G.; et al. World Sea-An Environmental Evaluation; Sheppard, C., Ed.; New Caledonia, France, 2019; pp. 593-618. Available online: https:/ / www.sciencedirect.com/book/9780081008539/world-seas-an-environmental-evaluation\#book-info (accessed on 7 June 2021). [CrossRef]

27. Ruiz-Barraud, M. Le parc de la mer de Corail est-il Toujours Protégé? La Nouvelle Calédonie. 2020. Available online: https: / /la1ere.francetvinfo.fr/nouvellecaledonie/le-parc-de-la-mer-de-corail-est-il-toujours-protege-879540.html (accessed on 7 June 2021).

28. Moity, N. Evaluation of No-Take Zones in the Galapagos Marine Reserve, Zoning Plan 2000. Front. Mar. Sci. 2018, 5, 244. [CrossRef]

29. La Direction des Affaires Maritimes (DAM)-Maritime Affairs. (NC government, Sept 2019) through the Pew Charitable Trusts. Available online: https://dtsi-sgt.maps.arcgis.com/apps/webappviewer/index.html?id=221a84b892254f6c8ce5cfc15a9b9d19 (accessed on 1 July 2020).

30. Kerr, J.; DeSalles, P.; Earle, S.A.; Kikiloi, K.S.; McCauley, D.; MacPherson, R.; Maxwell, S.; Richmond, R.; Roberts, C.; Spies, N.P.; et al. Pu'uhonua A Place of Sanctuary: The Cultural and Biological Significance of the Proposed Expansion for the Papahānaumokuākea Marine National Monument; 2016; Available online: https://nmspapahanaumokuakea.blob.core.windows.net/papahanaumokuakeaprod/media/archive/council/meetings/2016/puuhonua_a_place_of_sanctuary_submitted_by_william_aila_jr.pdf (accessed on 1 July 2020). [CrossRef] 
31. Marine Conservation Institute. MPAtlas [Online]. 2020. Available online: www.mpatlas.org (accessed on 18 May 2021).

32. Kitchingman, A.; Lai, S.; Morato, T.; Pauly, D. How many seamounts are there and where are they located? In Seamounts: Ecology Fisheries and Conservation; Pitcher, T.J., Morato, T., Hart, P., Clark, M., Haggan, N., Santo, R., Eds.; Blackwell Fish and Aquatic Resources Series: Oxford, UK, 2007; Volume 12, Chapter 2; pp. 26-40.

33. Pitcairn Islands Tourism. Pitcairn Islands Marine Reserve, One of the Largest in the World! 2019. Available online: https: //www.visitpitcairn.pn/marine_reserve/reserve/index.html (accessed on 1 July 2020).

34. Garibaldi, L. The FAO global capture production database: A six-decade effort to catch the trend. Mar. Policy 2012, 36, 760-768. [CrossRef]

35. Pauly, D. On the importance of fisheries catches, with a rationale for their reconstruction. In Global Atlas of Marine Fisheries: A Critical Appraisal of Catches and Ecosystem Impacts; Pauly, D., Zeller, D., Eds.; Island Press: Washington, DC, USA, 2016; pp. 1-11.

36. Zeller, D.; Booth, S.; Davis, G.; Pauly, D. Re-estimation of small-scale fishery catches for U.S. flag-associated island areas in the western Pacific: The last 50 years. U.S. Fish. Bull. 2007, 105, 266-277.

37. Pauly, D.; Zeller, D.; Palomares, M.L.D. (Eds.) Sea around Us Concepts, Design and Data; 2020; Available online: http://www. seaaroundus.org/citation-policy/ (accessed on 7 June 2021).

38. Zeller, D.; Booth, S.; Pauly, D. Reconstruction of Coral Reef- and Bottom Fisheries Catches for U.S. Flag Islands in the Western Pacific, 1950-2002; Report to the Western Pacific Regional Fishery Management Council: Honolulu, HI, USA, 2005; 113p.

39. Zeller, D.; Darcy, M.; Booth, S.; Lowe, M.; Martell, S. What about recreational catch?: Potential impact on stock assessment for Hawaii's bottom fish fisheries. Fish. Res. 2008, 91, 88-97. [CrossRef]

40. Chaitanya, D.; Harper, S.; Zeller, K. Reconstruction of total marine fisheries catches for the Pitcairn Islands (1950-2009). In Fisheries Catch Reconstructions: Islands, Part III; Harper, S., Zylich, K., Boonzaier, L., le Manach, F., Pauly, D., Zeller, D., Eds.; Fisheries Centre Research Report; 2012; Volume 20, pp. 87-94. Available online: https:/ / research-repository.uwa.edu.au/en/ publications / reconstruction-of-total-marine-fisheries-catches-for-the-pitcairn (accessed on 7 June 2021).

41. Schiller, L.; Alava, J.J.; Grove, J.; Reck, G.; Pauly, D. The demise of Darwin's fishes: Evidence of fishing down and illegal shark finning in the Galápagos Islands. Aquat. Conserv. Mar. Freshw. Ecosyst. 2014, 25, 431-446. [CrossRef]

42. Schiller, L.; Alava, J.-J.; Grove, J.; Reck, G.; Pauly, D. Ecuador (Galapagos). In Global Atlas of Marine Fisheries: A critical appraisal of Catches and Ecosystem Impacts; Pauly, D., Zeller, D., Eds.; Island Press: Washington, DC, USA, 2016; Volume 242.

43. Harper, S.; Frotté, L.; Bale, S.; Booth, S.; Zeller, D. Reconstruction of total marine fisheries catches for New Caledonia (1950-2007). In Fisheries Catch Reconstructions: Islands, Part I; Fisheries Research Reports; Zeller, D., Harper, S., Eds.; 2009; Volume 17, pp. 67-76.

44. Zeller, D.; Pauly, D. USA (Main Hawaiian Islands). In Global Atlas of Marine Fisheries: A Critical Appraisal of Catches and Ecosystem Impacts; Pauly, D., Zeller, D., Eds.; Island Press: Washington, DC, USA, 2016; Volume 446.

45. Chaitanya, D.; Harper, S.; Zeller, D. United Kingdom (Pitcairn Islands). In Global Atlas of Marine Fisheries: A Critical Appraisal of Catches and Ecosystem Impacts; Pauly, D., Zeller, D., Eds.; Island Press: Washington, DC, USA, 2016; Volume 433.

46. Harper, S.; Frotté, L.; Bale, S.; Booth, S.; Zeller, D. New Caledonia. In Global Atlas of Marine Fisheries: A Critical Appraisal of Catches and Ecosystem Impacts; Pauly, D., Zeller, D., Eds.; Island Press: Washington, DC, USA, 2016; Volume 264.

47. .White, R.; Derrick, B.; Abucay, L.; Ang, M.; Brown, C.; Popov, S.; Relano, V.; Zeller, D. Updated catch reconstructions for U.S.-flag associated Pacific island areas to 2018. In Updating to 2018 the 1950-2010 Marine Catch Reconstructions of the Sea around US. Part II: The Americas and Asia-Pacific; Fisheries Centre Research Report 28; Derrick, B., Khalfallah, M., Relano, V., Zeller, D., Pauly, D., Eds.; Institute for the Oceans and Fisheries at the University of British Columbia: Columbia, UK, 2020; pp. 230-248.

48. White, R.; Derrick, B.; Coulter, A.; Polido, R.; Cashion, T.; Parducho, V.; Sorongon-Yap, P.; De Leon, S.; Abucay, L.; Noël, S.-L.; et al. Updated catch reconstructions of Melanesia to 2018. In Updating to 2018 the 1950-2010 Marine Catch Reconstructions of the Sea Around Us. Part II: The Americas and Asia-Pacific; Derrick, B., Khalfallah, M., Relano, V., Zeller, D., Pauly, D., Eds.; Fisheries Centre Research Report; Institute for the Oceans and Fisheries at the University of British Columbia: Columbia, UK, 2020; Volume 28, pp. 187-211.

49. Page, E.; Derrick, B.; Coulter, A.; White, R.; Ang, M.; Dunstan, D.; Hood, L.; Relano, V.; Tsui, G.; van der Meer, L.; et al. South America: Updated catch reconstructions to 2018. In Updating to 2018 the 1950-2010 Marine Catch Reconstructions of the Sea around US. Part II: The Americas and Asia-Pacific; Derrick, B., Khalfallah, M., Relano, V., Zeller, D., Pauly, D., Eds.; Fisheries Centre Research Report; Institute for the Oceans and Fisheries at the University of British Columbia: Columbia, UK, 2020; Volume 28, pp. 279-312.

50. Coghlan, A.R.; White, R.; Dawson, T.P.; Irving, R.A.; Zeller, D.; Palomares, M.L.D. Reconstructed Marine Fisheries Catches at a Remote Island Group: Pitcairn Islands (1950-2014). Front. Mar. Sci. 2017, 4, 320. [CrossRef]

51. Pauly, D.; Christensen, V.; Dalsgaard, J.; Froese, R.; Torres, F. Fishing Down Marine Food Webs. Science 1998, $279,860-863$. [CrossRef] [PubMed]

52. Pauly, D.; Watson, R. Background and interpretation of the 'Marine Trophic Index' as a measure of biodiversity. Philos. Trans. R. Soc. Biol. Sci. 2005, 360, 415-423. [CrossRef]

53. Kleisner, K.; Mansour, H.; Pauly, D. Region-based MTI: Resolving geographic expansion in the Marine Trophic Index. Mar. Ecol. Prog. Ser. 2014, 512, 185-199. [CrossRef]

54. Liang, C.; Pauly, D. Fisheries Impacts on China's Coastal Ecosystems: Unmasking a Pervasive 'Fishing Down' Effect. PLoS ONE 2017, 12, e0173296. [CrossRef] [PubMed]

55. Walters, C.; Pauly, D.; Christensen, V. Ecospace: Prediction of Mesoscale Spatial Patterns in Trophic Relationships of Exploited Ecosystems, with Emphasis on the Impacts of Marine Protected Areas. Ecosystems 1999, 2, 539-554. [CrossRef] 
56. Roberts, C.M.; Bohnsack, J.A.; Gell, F.; Hawkins, J.P.; Goodridge, R. Effects of Marine Reserves on Adjacent Fisheries. Science 2001, 294, 1920-1923. [CrossRef]

57. Kellner, J.B.; Tetreault, I.; Gaines, S.D.; Nisbet, R.M. Fishing the line near marine reserves in single and multispecies fisheries. Ecol. Appl. 2007, 17, 1039-1054. [CrossRef]

58. Kroodsma, D.A.; Mayorga, J.; Hochberg, T.; Miller, N.A.; Boerder, K.; Ferretti, F.; Wilson, A.; Bergman, B.; White, T.D.; Block, B.A.; et al. Tracking the global footprint of fisheries. Science 2018, 359, 904-908. [CrossRef] [PubMed]

59. PitaGraham, C.; Pierce, G.; Theodossiou, I.; MacPherson, K. An overview of commercial fishers' attitudes towards marine protected areas. Hydrobiologia 2011, 670, 289-306.

60. Englander, G. Property rights and the protection of global marine resources. Nat. Sustain. 2019, 2, 981-987. [CrossRef]

61. Anticamara, J.A.; Watson, R.; Gelchu, A.; Pauly, D. Global fishing effort (1950-2010): Trends, gaps and implications. Fish. Res. 2011, 107, 131-136. [CrossRef]

62. Swartz, W.; Sala, E.; Tracey, S.; Watson, R.; Pauly, D. The Spatial Expansion and Ecological Footprint of Fisheries (1950 to Present). PLoS ONE 2010, 5, e15143. [CrossRef]

63. Watson, R.; Cheung, W.; Anticamara, J.; Sumaila, R.U.; Zeller, D.; Pauly, D. Global marine yield halved with increasing fishing intensity. Fish Fish. 2012, 14, 493-503. [CrossRef]

64. Salinas-de-León, P.; Andrade, S.; Arnés-Urgellés, C.; Bermudez, J.R.; Bucaram, S.; Buglass, S.; Cerutti, F.; Cheung, W.; De la Hoz, C.; Hickey, V.; et al. Evolution of the Galapagos in the Anthropocene. Nat. Clim. Chang. 2020, 10, 380-382. [CrossRef]

65. Coulter, A.; Cashion, T.; Cisneros-Montemayor, A.M.; Popov, S.; Tsui, G.; Le Manach, F.; Schiller, L.; Palomares, M.L.D.; Zeller, D.; Pauly, D. Using harmonized historical catch data to infer the expansion of global tuna fisheries. Fish. Res. 2019, 221, 105379. [CrossRef]

66. Lalande, C. Les trois Nouveaux Navires d'Armement du Nord prêts à Prendre la mer; Les Nouvelles Calédoniennes: New Caledonia, France, 2019.

67. Madec, A.; Cognard, N. Trois Palangriers neufs Rejoignent la flotte de Navimon. La 1ere. 17 January 2020. Available online: https:/ /a1ere.francetvinfo.fr/nouvellecaledonie/trois-palangriers-neufs-rejoignent-flotte-navimon-790463.html (accessed on 16 May 2021).

68. Mannevy, C. Ces palangrier plongent dans la pêche hauturière. La 1ere. 17 November 2020. Available online: https://la1ere. francetvinfo.fr/nouvellecaledonie/ces-palangriers-plonges-dans-la-peche-hauturiere-893572.html (accessed on 16 May 2021).

69. Day, J.; Dudley, N.; Hockings, M.; Holmes, G.; Laffoley, D.A.A.; Stolton, S.; Wells, S.M. Guidelines for Applying the IUCN Protected Area Management Categories to Marine Protected Areas; IUCN: Gland, Switzerland, 2012; 36p.

70. Burbano, D.V.; Meredith, T.C. Conservation Strategies Through the Lens of Small-Scale Fishers in the Galapagos Islands, Ecuador: Perceptions Underlying Local Resistance to Marine Planning. Soc. Nat. Resour. 2020, 33, 1194-1212. [CrossRef]

71. Global Fishing Watch. 2018. Available online: https:/ /globalfishingwatch.org/map/ (accessed on 18 May 2021).

72. Castro, X. Analysis of the Current Socio-Economic Situation of the 'Galapagos Artisanal Fishing Community'; Parque Nacional Galápagos/JICA (Japanese International Cooperation Agency): Galapagos, Ecuador, 2005.

73. Bremner, J.; Perez, J. A Case Study of Human Migration and the Sea Cucumber Crisis in the Galapagos Islands. AMBIO 2002, 31, 306-310. [CrossRef]

74. Hearn, A.; Martinez, P.; Toral-Granda, M.V.; Murillo, J.C.; Polovina, J. Population dynamics of the exploited sea cucumber Isostichopus fuscus in the western Galapagos Islands, Ecuador. Fish. Oceanogr. 2005, 14, 377-385. [CrossRef]

75. Buglass, S.; Reyes, H.; Ramirez-González, J.; Eddy, T.D.; Salinas-De-León, P.; Jarrin, J.M. Evaluating the effectiveness of coastal no-take zones of the Galapagos Marine Reserve for the red spiny lobster, Panulirus penicillatus. Mar. Policy 2018, 88, $204-212$. [CrossRef]

76. Cerutti-Pereyra, F.; Moity, N.; Dureuil, M.; Ramírez-González, J.; Reyes, H.; Budd, K.; Jarrín, J.M.; Salinas-De-León, P. Artisanal longline fishing the Galapagos Islands -effects on vulnerable megafauna in a UNESCO World Heritage site. Ocean Coast. Manag. 2019, 183, 104995. [CrossRef]

77. Grove, J.S. The Global Sport Fishing Industry and impact on the Galapagos Marine Protected Area. J. Aquac. Mar. Biol. 2017, 5, 00124.

78. Cramer, J.L.; Nakamura, R.M.; Dizon, A.E.; Ikehara, W.N. Burnt tuna: Conditions leading to rapid deterioration in the quality of raw tuna. Mar. Fish. Rev. 1981, 43, 12-16.

79. Brownscombe, J.W.; Danylchuk, A.J.; Chapman, J.M.; Gutowsky, L.; Cooke, S. Best practices for catch-and-release recreational fisheries-Angling tools and tactics. Fish. Res. 2017, 186, 693-705. [CrossRef]

80. Cooke, S.J.; Sneddon, L. Animal welfare perspectives on recreational angling. Appl. Anim. Behav. Sci. 2007, 104, 176-198. [CrossRef]

81. Bucaram, S.J.; Hearn, A.; Trujillo, A.M.; Rentería, W.; Bustamante, R.H.; Morán, G.; Reck, G.; García, J.L. Assessing fishing effects inside and outside an MPA: The impact of the Galapagos Marine Reserve on the Industrial pelagic tuna fisheries during the first decade of operation. Mar. Policy 2018, 87, 212-225. [CrossRef]

82. Hearn, A. The rocky path to sustainable fisheries management and conservation in the Galápagos Marine Reserve. Ocean Coast. Manag. 2008, 51, 567-574. [CrossRef]

83. Usseglio, P. The Galapagos Grouper Fishery: Mostly Dead, Stunned, or in Need of Management Regulations? Ph.D. Thesis, University of Hawaii at Manoa, Honolulu, HI, USA, 2015. 
84. Zimmerhackel, J.S.; Schuhbauer, A.C.; Usseglio, P.; Heel, L.C.; Salinas-De-León, P. Catch, bycatch and discards of the Galapagos Marine Reserve small-scale handline fishery. PeerJ 2015, 3, e995. [CrossRef] [PubMed]

85. Camhi, M. Industrial Fisheries Threaten Ecological Integrity of the Galapagos Islands. Conserv. Biol. 1995, 9, 715-719. [CrossRef]

86. Collyns, D. Chinese Fishing Armada Plundered Waters around Galápagos, Data Shows. The Guardian. 2020. Available online: https:/ / www.theguardian.com/environment/2020/sep/17/chinese-fishing-armada-plundered-waters-around-galapagosdata-shows (accessed on 1 June 2021).

87. Ford, A. Chinese Fishing Fleet Leaves Ecuador, Chile, Peru Scrambling to Respond. Insight Crime. 2020. Available online: https://insightcrime.org/news/analysis/china-fishing-fleet-response/ (accessed on 1 June 2021).

88. De Santo, E.M.; Mendenhall, E.; Nyman, E.; Tiller, R. Stuck in the middle with you (and not much time left): The third intergovernmental conference on biodiversity beyond national jurisdiction. Mar. Policy 2020, 117, 103957. [CrossRef]

89. Sumaila, U.R.; Lam, V.W.Y.; Miller, D.; Teh, L.; Watson, R.; Zeller, D.; Cheung, W.W.L.; Côté, I.M.; Rogers, A.D.; Roberts, C.; et al. Winners and losers in a world where the high seas is closed to fishing. Sci. Rep. 2015, 5, 8481. [CrossRef]

90. Okey, T.A.; Banks, S.; Born, A.F.; Bustamante, R.H.; Calvopiña, M.; Edgar, G.J.; Espinoza, E.; Fariña, J.M.; Garske, L.E.; Reck, G.K.; et al. A trophic model of a Galápagos subtidal rocky reef for evaluating fisheries and conservation strategies. Ecol. Model. 2004, 172, 383-401. [CrossRef]

91. Ventura, F.; Matthiopoulos, J.; Jeglinski, J.W. Minimal overlap between areas of high conservation priority for endangered Galapagos pinnipeds and the conservation zone of the Galapagos Marine Reserve. Aquat. Conserv. Mar. Freshw. Ecosyst. 2018, 29, 115-126. [CrossRef]

92. Cabral, R.B.; Gaines, S.D.; Johnson, B.A.; Bell, T.W.; White, C. Drivers of redistribution of fishing and non-fishing effort after the implementation of a marine protected area network. Ecol. Appl. 2017, 27, 416-428. [CrossRef]

93. WPRFMC. Western Pacific Regional Fishery Management Council (WPRFMC); Workshop on Pacific Bigeye Movement and Distribution: 2014; Western Pacific Regional Fishery Management Council: Hawaii, USA; Available online: http://www.wpcouncil.org/ wp-content/uploads/2014/11/Final-Bigeye-Workshop-Report.pdf (accessed on 1 June 2021).

94. De Santo, E.M. Missing marine protected area (MPA) targets: How the push for quantity over quality undermines sustainability and social justice. J. Environ. Manag. 2013, 124, 137-146. [CrossRef]

95. UN General Assembly, Convention on the Law of the Sea, 10 December 1982. Available online: https://www.refworld.org/ docid/3dd8fd1b4.html (accessed on 9 June 2021).

96. Dunn, D.C.; Jablonicky, C.; Crespo, G.O.; McCauley, D.J.; Kroodsma, D.A.; Boerder, K.; Gjerde, K.M.; Halpin, P.N. Empowering high seas governance with satellite vessel tracking data. Fish Fish. 2018, 19, 729-739. [CrossRef]

97. Palomares, M.L.D.; Froese, R.; Derrick, B.; Meeuwig, J.J.; Nöel, S.-L.; Tsui, G.; Woroniak, J.; Zeller, D.; Pauly, D. Fisheries Biomass Trends of Exploited Fish Populations in Marine Ecoregions, Climatic Zones and Ocean Basins. Estuar. Coast. Shelf Sci. 2020, 243, 106896. Available online: https://www.sciencedirect.com/science/article/pii/S0272771419307644\#sec5 (accessed on 9 June 2021). [CrossRef]

98. Agnalt, A.L.; Jørstad, K.E.; Kristiansen, T.S.; Nøstvold, E.; Farestveit, E.; Næss, H.; Paulsen, O.I.; Svåsand, T. Stock Enhancement and Sea Ranching: Developments, Pitfalls and Opportunities, Enhancing the European Lobster (Homarus gammarus) Stock at Kvitsøy Islands: Perspectives of Rebuilding Norwegian Stocks; Leber, K.M., Kitada, S., Blankenship, H.L., Svåsen, S., Eds.; Blackwell Publishing Ltd.: Oxford, UK, 2004; pp. 415-426.

99. Armstrong, C.W.; Eide, A.; Flaaten, O.; Heen, K.; Kaspersen, I.W. Rebuilding the Northeast Arctic cod fisheries-Economic and social issues. Arct. Rev. Law Politics 2014, 5, 11-37.

100. Heery, E.; Cope, J.M. Co-occurrence of bycatch and target species in the groundfish demersal trawl fishery of the U.S. west coast; with special consideration of rebuilding stocks. Fish. Bull. 2014, 112, 36-48. [CrossRef]

101. Milazzo, M.J. Progress and problems in U.S. marine fisheries rebuilding plans. Rev. Fish Biol. Fish. 2012, 22, 273-296. [CrossRef]

102. Sandberg, P.; OECD. The Economics of Rebuilding-Workshop Proceedings. Rebuilding the Stock of Norwegian Spring Spawning Herring: Lessons Learned; OECD, Ed.; OECD Publishing: Paris, France, 2010; pp. 219-233.

103. Vrancken, P. State jurisdiction to investigate and try fisheries crime at sea. Mar. Policy 2019, 105, 129-139. [CrossRef]

104. Divovich, E.; Belhabib, D.; Zeller, D.; Pauly, D. Canada (East Coast). Global Atlas of Marine Fisheries: A Critical Appraisal of Catches and Ecosystem Impacts; Pauly, D., Zeller, D., Eds.; Island Press: Washington, DC, USA, 2016; pp. 151-215.

105. Devillers, R.; Pressey, R.L.; Ward, T.J.; Grech, A.; Kittinger, J.N.; Edgar, G.J.; Watson, R.A. Residual marine protected areas five years on: Are we still favouring ease of establishment over need for protection? Aquat. Conserv. Mar. Freshw. Ecosyst. 2020, 30, 1758-1764. [CrossRef]

106. Kikiloi, K.; Friedlander, A.M.; Wilhelm, A.; Lewis, N.; Quiocho, K.; 'Āila, W.; Kaho'ohalahala, S. Papahānaumokuākea: Integrating Culture in the Design and Management of one of the World's Largest Marine Protected Areas. Coast. Manag. 2017, 45, 436-451. [CrossRef]

107. Thiault, L.; Jupiter, S.D.; Johnson, J.E.; Cinner, J.E.; Jarvis, R.M.; Heron, S.F.; Maina, J.M.; Marshall, N.A.; Marshall, P.A.; Claudet, J. Harnessing the potential of vulnerability assessments for managing social-ecological systems. Ecol. Soc. 2021, 26, 1. [CrossRef]

108. Asher, J.; Maragos, J.; Kenyon, J.; Vargas-Ángel, B.; Coccagna, E. Range extensions for several species of Acropora in the Hawaiian Archipelago and the Papahānaumokuākea Marine National Monument. Bull. Mar. Sci. 2012, 88, 337-338. [CrossRef]

109. Tsuda, R.T.; Spalding, H.L.; Sherwood, A.R. New species records of marine benthic algae in the Papahānaumokuākea Marine National Monument (Northwestern Hawaiian Islands). Bishop Mus. Occas. Pap. 2015, 116, 41-47. 
110. Friedlander, A.; Aeby, G.; Brainard, R.; Clark, A.; DeMartini, E.; Godwin, S.; Kenyon, J.; Kosaki, R.; Maragos, J.; Vroom, P. The state of coral reef ecosystems of the Northwestern Hawaiian Islands. In The State of Coral Reef Ecosystems of the United States and Pacific Freely Associated States; Waddell, J., Ed.; NOAA Technical Memorandum NOS NCCOS 11, 2005; NOAA/NCCOS Center for Coastal Monitoring and Assessment's Biogeography Team: Silver Spring, MD, USA, 2005; pp. $270-311$.

111. Selkoe, K.A.; Halpern, B.S.; Ebert, C.M.; Franklin, E.C.; Selig, E.R.; Casey, K.S.; Bruno, J.; Toonen, R.J. A map of human impacts to a "pristine" coral reef ecosystem, the Papahānaumokuākea Marine National Monument. Coral Reefs 2009, 28, 635-650. [CrossRef]

112. Hays, G.C.; Koldewey, H.J.; Andrzejaczek, S.; Attrill, M.J.; Barley SBayley, D.T.; Benkwitt, C.E.; Block, B.; Schallert, R.J.; Carlisle, A.B.; Carr, P. A review of a decade of lessons from one of the world's largest MPAs: Conservation gains and key challenges. Mar. Biol. 2020, 167, 1-22. [CrossRef]

113. Duarte, C.M.; Agusti, S.; Barbier, E.; Britten, G.L.; Castilla, J.C.; Gattuso, J.-P.; Fulweiler, R.W.; Hughes, T.P.; Knowlton, N.; Lovelock, C.E.; et al. Rebuilding marine life. Nature 2020, 580, 39-51. [CrossRef] [PubMed] 